\title{
The internationalization of Austrian firms in Central and Eastern Europe*
}

\author{
Schien Ninan, Jonas F Puck**
}

We test and expand the Uppsala model with a sample of 109 Austrian companies active in the CEE region, representing 1,271 entries. On the one hand, our expansion of the model is based on collective learning of firms from a specific context, an issue largely neglected in IB research. On the other hand, we expand the model by including two further strategic, i.e. dependent, variables. The paper contributes to research by finding three distinct internationalization processes in CEE, two of them new to the Uppsala Model. Furthermore, the paper strongly supports our argumentation with regard to collective learning and thereby draws new conclusions on learning processes that take place within and between firms over time.

Dieser Beitrag testet und erweitert das Uppsala Modell anhand eines Samples von 1.271 Markteintritten durch 109 österreichische Firmen in der CEE Region. Unsere Erweiterung bezieht sich einerseits auf kollektives Lernen, ein Phänomen welches bisher in der IB Literatur weitgehend vernachlässigt wurde. Andererseits erweitern wir das Modell durch die Einbeziehung von zwei weiteren abhängigen Variablen. Der Artikel leistet einen Beitrag zur Forschung in dem drei unterschiedliche Internationalisierungsprozesse, zwei davon neu für das Uppsala Model, identifiziert werden. Darüber hinaus unterstützen die Ergebnisse unsere Argumentation des kollektiven Lernens. Dies lässt neue Schlüsse in Bezug auf Lernprozesse, welche innerhalb aber auch zwischen Firmen stattfinden, $z u$.

Key words: Austrian companies, CEE region, internationalization processes

* Manuscript received: 25.01.10, accepted: 26.05.10 (1 revision)

** Schien Nianan, Dr., Institute for International Business, Department of Cross - Border Business, WU Vienna, Austria. Main research areas: Internationalization of firms, Central and Eastern Europe. Corresponding address: schien.ninan@wu.ac.at.

Jonas F Puck, Dr., Prof., Institute for International Business, Department of Cross -Border . Business, WU Vienna, Austria. Main research areas: Emerging markets, high risk countries and diverse team. Corresponding address: jonas.puck@wu.ac.at. 


\section{Introduction}

From a European perspective, the fall of the iron curtain in 1989 was the change factor in modern history. This change has encompassed all areas of society and has led to a strong integration process of what was once known as a divided Europe. As a consequence, both trade and FDI flows between Central and Eastern Europe (CEE) and other countries have increased over the last two decades (UNCTAD 2009). Therefore, the internationalization of firms in the CEE region represents a strong opportunity for research in international business (Gelbuda/Meyer/Delios 2008; Meyer/Gelbuda 2006). At present, we are in the midst of this greater internationalization process. Enough time has passed in order to obtain sufficient amounts of internationalization data, and enough time lies before us to implement lessons learned from the past. Thus, the developments in Central and Eastern Europe provide a unique opportunity to test the generalization ability of existing theories. Furthermore, the application of theories to this new context might also trigger new theoretical developments (Meyer/Peng 2005).

However, while a large body of research has dealt with entry mode choice in general (Agarwal/Ramaswami 1992; Anderson/Gatignon 1987; Tihanyi/ Griffith/Russell 2005; Woodcock/Beamish/Makino 1994; Zhao/Luo/Suh 2004) there is comparatively limited empirical evidence on internationalization processes in this region. We have compiled a table of papers in the appendix dealing with the internationalization of firms in CEE. Following, we provide some examples of past research.

Early studies such as Engelhard and Eckert (1995), and Sharma (1995) were novel in their effort to describe early internationalization paths of western firms in the CEE region. Both studies, the former analyzing 268 German firms, the latter analyzing 166 U.S. firms find a step by step internationalization process of western firms entering the region. Subsequent studies are narrower in their research design by either focusing on foreign direct investment modes, or focusing on special aspects of the internationalization process. Lankes and Venables (1996) for instance, conduct a survey of 117 western manufacturing companies mainly analyzing the motivation behind different types of foreign direct investments. Uhlenbruck (1997) looks at performance implications of foreign direct investments in CEE. He however only focuses on acquisitions made due to privatization. Other researchers put a stronger emphasis on environmental factors influencing firms' internationalization in the region. Sharma (2000) analyzes U.S. companies' entry strategies and their determinants into Russia, the Czech Republic, Hungary, Poland and Romania. In the study he concludes that company factors such as business activity, and year of entry, as well as market factors such as level of competition and market potential have an influence on firms' choice of entry mode. Salmi (2000) focuses on a turbulent phase of Estonia's economic history from 1991 to 1994, adapting a holistic 
network approach while looking at the internationalization of a western firm. Host country institutions' effect on transaction cost reduction and its subsequent impact on entry mode choice of German and British firms is subject of Meyer's (2001) research. Nakos and Brouthers (2002) analyze the entry mode choice of Greek SMEs in CEE by employing Dunning's eclectic framework. They find the OLI framework to be useful in predicting firms' mode choices. A different methodical approach is employed by Johanson and Johanson (2006), who follow a longitudinal case study design, analyzing the market entry of a Swedish firm in the Russian market between 1987 and 1993. They highlight learning processes that occur through discovery and market turbulence. Learning is also the focus of Barkema and Drogendijk (2007), who more recently analyzed the internationalization steps of Dutch companies in CEE, identifying strategic choices firms have in terms of learning. In their study they focus on the internationalization paths of firms already active via FDI in the region. A summary of existing studies focusing on internationalization into CEE is provided in a table in the Appendix. Overall, one can conclude that with the notable exception of early studies most recent studies have either focused on rather specific aspects of internationalization (e.g. only including FDI modes), have used a case study approach, or have focused on a certain time period. Without intending to reduce the relevance of these studies, a broad and generalizable empirical study on internationalization processes covering a longer timeframe is, thus, still missing.

From a theoretical perspective, many theories provide knowledge about the internationalization process of firms. However, within this context the Uppsala Model (also known as internationalization process model) received specific attention. Many Authors applied it in order to explain the internationalization of firms in various situations and scenarios (Barkema/Drogendijk 2007; Claver/Rienda/Quer 2007; Liu/Xiao/Huang 2008). The Uppsala Model focuses on core elements of the internationalization process. It covers the geographic scope of such processes, and describes modes in which firms enter markets and later develop in these markets. Moreover, the model focuses on learning processes, which are especially important when understanding the internationalization of firms towards the CEE markets, since knowledge about transition markets can hardly be achieved prior to the investment for the reason of strong market dynamics. Internationalization towards this region was mostly only possible from 1990 onwards and involved intensive learning in new surroundings, very different from home market conditions (Meyer/Gelbuda 2006; Barkema/Drogendijk 2007) ${ }^{1}$. Despite the known criticism of the model, which is discussed in the limitations section of this paper, we as such believe

1 As we will later show in Figure 4, 77\% of all entries in our sample took place after 1990. 
that the Uppsala Model is best suited to analyze the fit of an existing dynamic theory on the internationalization of firms in the CEE environment.

In addition to this relevance for international business research, understanding the internationalization of firms in CEE is especially important from an Austrian viewpoint. Because of its historical and geographical location, Austria is one of the central proponents in European integration (Breuss 2006:3-4). It is one of the, in some countries even the biggest investor in CEE in spite of the relatively small size of the economy compared to other European countries (Oesterreichische Nationalbank 2005; Wiener Institut für Internationale Wirtschaftsvergleiche 2007; Wirtschaftskammern Österreichs 2005). In addition, foreign direct investment from Austria into the CEE region has tremendously grown within the last years, more than doubling from 2003 to 2006, today reaching an FDI stock of almost 40 billion Euro (Oesterreichische Nationalbank 2009).

Despite this practical relevance of the topic, the internationalization of Austrian firms into Central and Eastern Europe has not been comprehensively researched, although it is of pivotal significance for the Austrian economy. Consequently, it is crucial to understand the internationalization of Austrian companies towards Central and Eastern Europe. This understanding is important for businesses planning to enter, or further expand in the region, as well as for assisting organizations, and teachers, who influence future managers. Overall, we therefore believe that a dynamic perspective on firm internationalization in CEE using the Uppsala model as research framework has the potential to contribute to both theory and practice.

In our study, which covers the internationalization processes of 109 Austrian firms representing 1,271 entries in the CEE region over a period of 20 years we apply a longitudinal approach and go beyond the Uppsala model by comparing firms early internationalization in the region to the internationalization of today. We do so, since we believe that learning does not only happen within firms, but also, partially intended and partially unintended, between firms. By comparing early internationalization to today's internationalization in the region, we can thus draw conclusions on collective learning processes, which could otherwise not be drawn.

Overall, this paper thus intends to 1) test the applicability of the Uppsala model in this context, and 2) extend the Uppsala model by including a collective learning perspective. After the introductory section, we therefore present the core concepts of the Uppsala Model. We next use the model to develop two hypotheses regarding the internationalization of Austrian firms in the CEE region, followed by a tripartite third hypothesis based on the concepts of collective and individual learning. In the following section, we present our study's research design and methodology. Sample, data collection and processing are laid out. Findings and discussions are presented subsequently. 
This section is divided into descriptive results and hypotheses testing. Finally, we close the paper with a conclusion, implications and limitations.

\section{A process perspective of firm internationalization}

Based on the empirical evidence of Johanson and Wiedersheim-Paul (1975), Johanson and Vahlne (1977) developed their "internationalization model" (see Figure 1). It consists of four elements. Two "state aspects", being market knowledge and market commitment and two "change aspects", namely commitment decisions and current activities. The four elements are linked in a causal cycle: Through growing experience in a market the firm acquires market knowledge, thereby finding new opportunities in the market. The identification of newfound opportunities influences its commitment decisions and current activities, which are subsequently increased in order to exploit the opportunities. This in turn raises market commitment. Then the increased market commitment enables the firm to again acquire market knowledge and keeps the cycle moving. Summarizing, the main idea behind the model is that the current state of internationalization strongly affects the future internationalization of a company as the firm learns through experience (Johanson/Vahlne 1990).

Figure 1. The internationalization model

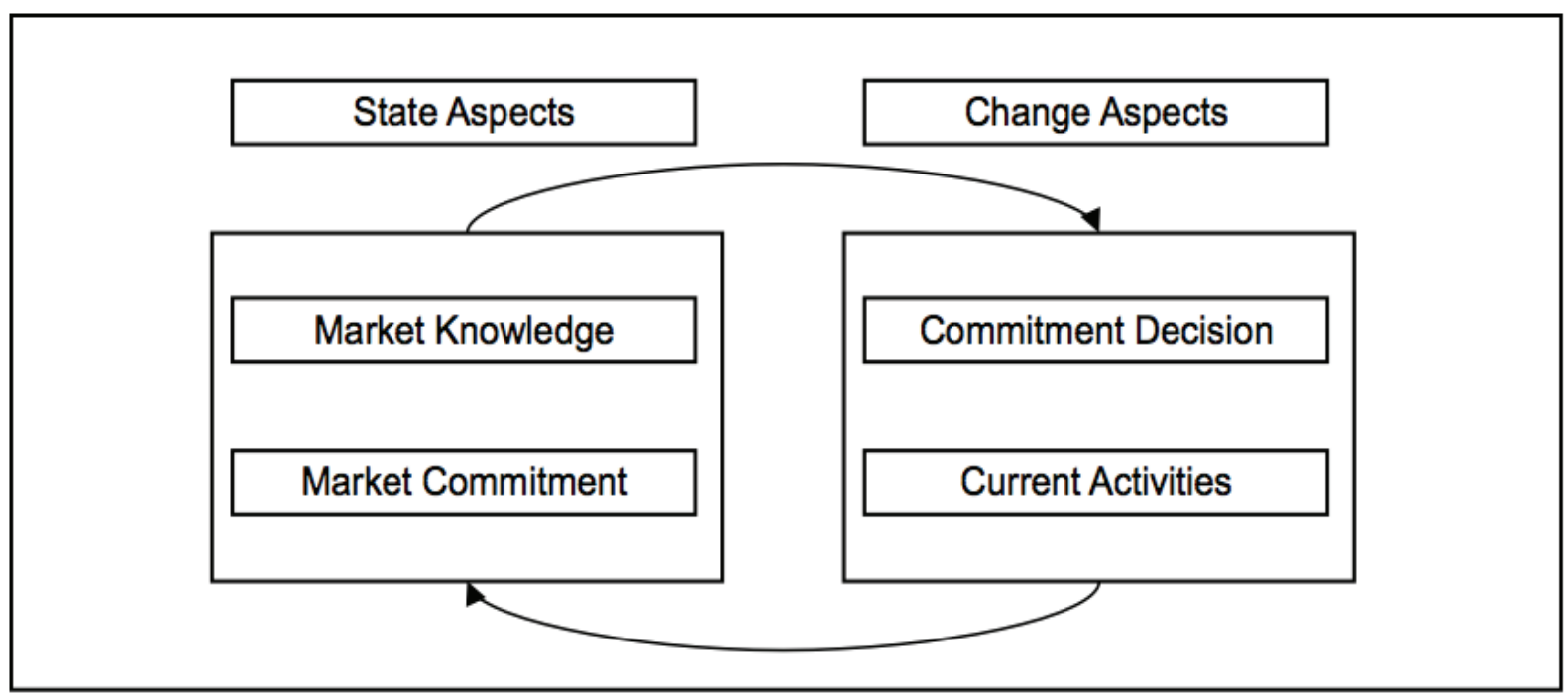

Source: Based on Johanson and Vahlne (1977:26)

In their research Johanson and Wiedersheim-Paul (1975) realize that the firm's incremental learning process in foreign markets is reflected in the development of its modes in these markets. They identify a process of growing resource commitment in foreign markets over time and label it "the establishment chain" (Johanson/Wiedersheim-Paul 1975:307). The establishment chain is divided into four stages through which firms progress: Firms enter foreign, unknown markets carefully via periodic exports. They then commit themselves more by exporting 
via independent representatives (agents), thereby gaining enough market knowledge in order to establish their own sales subsidiaries. The highest form of resource commitment finally is the establishment of a foreign production/manufacturing unit, which requires substantial market knowledge and marks the end of the internationalization process.

Tracing the early years of internationalization of Austrian firms in the CEE region, we would expect them not to have had much substantial market knowledge of the former communist markets, especially compared to other industrialized markets. High uncertainty and risk would have led them to carefully enter CEE markets in low entry modes. Over time, firms' market knowledge would grow, and as explained through the Uppsala Model so would market commitment. With growing market knowledge and market commitment firms would be more able and willing to take greater risks. Therefore, we would expect them to develop their operations into higher modes over time. In their case study of the entry of Swedish Karlshamns in Russia, Johanson and Johanson (2006) for instance show how through growing experience in the market the Swedish firm together with a local partner is able to identify and exploit new opportunities in the Russian market and thereby enhances its operations. Salmi (2000) provides an example of a western firm entering the Estonian market via export and finally direct investing after increasing its knowledge and local business relationships. In line with the described learning process, we thus derive our first hypothesis from the internationalization model and the establishment chain:

H1: In the early years of CEE internationalization, firms entered markets of the region in low entry modes, and then consistently moved on to higher modes in these markets over time.

According to the Uppsala Model the learning process in internationalization is not only reflected in entry modes, but also in the sequence in which firms enter different foreign markets. Johanson and Wiedersheim-Paul (1975) point out the influence of Psychic Distance on this sequence of foreign market entry. Psychic Distance is defined as: "factors preventing or disturbing the flows of information between firm and market. Examples of such factors are differences in language, culture, political systems, level of education, level of industrial development, etc." (Johanson/Wiedersheim-Paul 1975:308). As mentioned before, the incremental character of internationalization in the beginning of an internationalization process is largely attributed to the lack of market information. This lack of market information is strongly influenced by Psychic Distance. Markets with different languages, cultures, political or economic systems, etc. are less known, less familiar. Thus, large Psychic Distance keeps firms from entering certain markets, and countries with low Psychic Distance are entered first (Child/Ng/Wong 2002). However, once markets are entered, the firm digests Psychic Distance over time through learning processes, and the 
market becomes more and more familiar. Through this gained knowledge the Psychic Distance to other markets is also further reduced, formerly not considered markets can now be entered. Dow (2000:51) for instance states: "The impact of psychological distance on market selection appears to decrease substantially after the first market entry decision but remains a significant predictor." We expect the same to apply to the internationalization of Austrian companies to the CEE region. Thus, we derive the following hypothesis:

H2: In the early years of CEE internationalization, Austrian firms first entered markets with low Psychic Distance, before entering markets with higher Psychic Distance.

On the single firm side, overall market knowledge grows with the number of markets a firm enters within the region and, thus, markets are more familiar. In consequence, firms seek and exploit more opportunities and commitment in the region increases. Therefore, firms' CEE internationalization of today is likely to be different from its internationalization in the early years (see hypotheses 1 and 2). However, in addition to the described internal learning processes, Meyer and Gelbuda (2006) also highlight the importance of the external environment for processes of learning and resource allocations. In this context they emphasize cognitive and political factors among others, which influence learning. Taking these environmental factors into account, we believe that learning does not only happen within firms, but also between firms from specific industries or even countries. In other words, we believe that experiences of single firms affect the knowledge of other firms from the same context - an effect we call 'collective learning'.

Throughout the Austrian economy collective knowledge of the CEE region has grown over the last 20 years, thereby adding to the other factors described, enabling Austrian firms to enter these markets in higher modes. This is in line with the free rider effects known in strategic management: free riders are able to make their way into the market and do not spend the money or risk the failures which the first movers did. This reasoning goes beyond the actual Uppsala model since we expect firms without experience in the region to have learned from experienced firms, thus leading to higher entry modes and the formulation of our hypothesis:

H3a: Compared to the early years of CEE internationalization, Austrian firms today enter markets of the region in higher entry modes.

Furthermore, we expect the effects of learning processes not only to reflect in higher market entry modes. Due to increased knowledge achieved by both individual and collective learning, we also expect the number of mode changes to reduce. This however, has to our knowledge not been researched before, but can be derived from the following line of reasoning. In the early years of internationalization in the region, firms have to adapt their mode choices more 
often. They enter largely unknown markets, learn, and then continuously adapt their modes as described by the Uppsala model (Johanson/Wiedersheim-Paul 1975). With growing experience, either achieved by themselves or through the before mentioned collective learning process, their ability to forecast and to plan improves. Therefore, mistakes made by the focal firm or others in the past will not have to be made again, thus allowing late entrants to 'free ride' on the experiences of the first movers.

Lastly, today's overall higher levels of individual and collective market knowledge and higher commitment, not only enable firms to enter markets more rapidly and with fewer mode changes compared to early internationalization. They also enable firms to reach higher levels of the establishment chain, in other words to reach higher modes and progress further in the internationalization process (Bäurle 1996:71; Blomstermo/Sharma 2003:25). Again, this has, to the best of our knowledge, not been studied before, but represents a logical extension of the Uppsala model that implies that higher modes are preferred final modes. Based on the above arguments we derive the following two hypotheses:

H3b: Compared to the early years of CEE internationalization, Austrian firms today change their mode less often.

H3c: Compared to the early years of CEE internationalization, Austrian firms today reach higher modes.

\section{Sample, data collection and data processing}

The empirical study focuses on the internationalization of Austrian firms towards the Central and Eastern European markets. The Austrian Chamber of Commerce and its affiliates in the region have provided a list of Austrian firms active in these markets. Overall almost 2,000 Austrian firms are currently active in the region. As the Uppsala Model focuses on industrial firms and their internationalization modes, firms, which are mainly service providers, were eliminated from the list. Firms active in only one or two markets were also eliminated - they would not have provided enough data to analyze. The final list contained 390 firms. From these firms, managers responsible for the international business were interviewed. Contact data of the interview partners was either gathered from the internet homepage, or was included in the data provided by the Austrian Chamber of Commerce. The response rate was $28 \%$ (109 out of 390 firms contacted participated in the empirical study). The interviews were conducted in German, the native language of all interviewees. Respondents were very cooperative, most also offered to participate in further studies. Since interviews were only carried out with senior managers responsible for the international business of the firm and interviews had a minimum length of 20 minutes, the response rate is more than satisfactory compared to previous studies. 
Data was collected via computer-aided telephone interviews. These were carried out throughout October 2008. Telephone interviews were preferred to a fill-in questionnaire mainly due to the complex nature of the topic. The interview technique firstly leaves enough room for clarifying questions in case of misunderstandings. Secondly, it enables more elaborate answers. Furthermore, telephone interviews yield a higher response rate than written questionnaires. In addition, the use of computer-aided telephone interviews enabled us to use a dynamic interview guide, which quickly selected the correct interview paths depending on responses. With the help of the computer system, answers were directly entered into a database. Before the interviews were carried out secondary data such as information drawn from the company homepage, business reports, member indices and periodical articles were collected. By doing so, the time needed for the interviews could be reduced, since these only had to concentrate on the subjects not yet published. In addition, the validity of the interviews could be increased and the respondents could be questioned about concrete facts derived from the analyzed documents.

The interview guide followed general recommendations for interviews (Daniels/Cannice 2004) and included a number of closed, as well as open questions derived from previous research on the Uppsala Model (Engelhard/Blei 1996; Nordström 1991). The guide was pilot tested beforehand several times, subsequently modified and fine-tuned. Firms were contacted and senior managers responsible for the international business of the firm in Central and Eastern Europe were identified. In all cases we ensured that interviews were carried out with these senior managers and not with firm representatives responsible for external relations. After a brief introduction to the topic and the questions to be asked during the main interview, a separate date for the main telephone interview was fixed. This procedure made it possible for managers to collect additional data before the actual interview if required.

The main section of the interview focused on the validation and extension of internationalization data collected beforehand through publicly available sources. While in most cases information on market entry timings could be collected beforehand, information on specific entry modes had often to be obtained through the interview. With regard to entry modes, respondents were first given a choice between export, licensing, contract manufacturing, and direct investment. Exports were then further divided into indirect export, export cooperation, and direct export. Direct investments were further divided into wholly owned sales subsidiaries, sales joint ventures, wholly owned manufacturing subsidiaries, and manufacturing joint ventures. Respondents were then asked how the firm changed its entry modes in the due course of time in the given countries. The final section of the interview validated and extended data on the economic background of the firm with regard to firm age, number of employees, sales in million Euro, percentage of employees located in CEE, 
percentage of revenue made in CEE, as well as the firm industry. We believe that our two-folded strategy of validating data obtained by secondary research through the interviews, as well as providing managers with the possibility to collect data before the actual interview reduced memory bias.

After data collection the interviews were transcribed in full and processed with the software program NVivo. As protocol technique the transcription in normal writing was applied. Since the focus of the interviews was laid on contents and subjects, dialectal phrases were adjusted and mistakes in grammar and style were corrected. Important information in addition to the protocol was recorded as commented transcriptions.

Besides the personal interviews additional secondary data such as the Hofstede (2008) scores were included for further analyses. Given the standardized nature of the interviews, quotation analysis was applied to generate comparable and quantifiable data output. In consequence, we developed a database that combined the information stemming from primary and secondary sources. This database builds the empirical base to test our hypotheses and contains information about the CEE internationalization processes of 109 Austrian firms as well as the above-mentioned secondary data.

\section{Findings and discussion}

\section{Descriptive results}

Descriptive results show that almost one fifth of the firms in the sample have a very long tradition and were founded over 100 years ago. The period from 1950 to 1989 seems to have been the most fertile, with about $52 \%$ of the founding's stemming from this time. $10.2 \%$ of all firms were created in the last 20 years.

A significant portion of medium, as well as large companies were found in the population. About $17.6 \%$ of the firms had 1 to 100 employees. $38 \%$ had between 101 and 1,000 employees, and 44.4\% more than 1001 employees. The importance of the Central and Eastern European Region is very high for the surveyed firms; almost $57 \%$ of all firms generate more than a quarter of their sales in the region. Over $9 \%$ even generate more than three quarters of their sales in CEE. The number of CEE countries in which the firms are active is evenly distributed. About $12 \%$ of all surveyed firms are active in all markets; almost $60 \%$ are active in ten or more markets (see Figure 2 and 3). 
Figure 2. Sample data of 2008

\begin{tabular}{|c|c|c|c|c|c|}
\hline \multicolumn{2}{|l|}{ Firm Age } & \multicolumn{2}{|l|}{ Employees } & \multicolumn{2}{|c|}{ Sales in million Euro } \\
\hline $0-20$ & $10,2 \%$ & $0-50$ & $6,4 \%$ & $0-10$ & $15,2 \%$ \\
\hline $21-40$ & $26,9 \%$ & $51-100$ & $11,2 \%$ & $11-50$ & $28,3 \%$ \\
\hline $41-60$ & $23,1 \%$ & $101-500$ & $25,7 \%$ & $51-100$ & $18,5 \%$ \\
\hline $61-80$ & $8,3 \%$ & $501-1000$ & $12,3 \%$ & $101-500$ & $26,1 \%$ \\
\hline $81-100$ & $11,1 \%$ & $1001-5000$ & $24,2 \%$ & $501-1000$ & $6,5 \%$ \\
\hline$>100$ & $20,4 \%$ & $>5000$ & $20,2 \%$ & $>1000$ & $5,4 \%$ \\
\hline \multicolumn{3}{|c|}{ \% Employees in CEE } & \multicolumn{3}{|c|}{$\%$ Revenue from CEE } \\
\hline $0-25 \%$ & & $45,9 \%$ & $0-25 \%$ & \multicolumn{2}{|c|}{$43,4 \%$} \\
\hline $26-50 \%$ & & $25,7 \%$ & $26-50 \%$ & \multicolumn{2}{|c|}{$29,0 \%$} \\
\hline $51-75 \%$ & & $19,3 \%$ & $51-75 \%$ & \multicolumn{2}{|c|}{$18,3 \%$} \\
\hline $76 \%-100 \%$ & & $9,2 \%$ & $76 \%-100 \%$ & \multicolumn{2}{|c|}{$9,3 \%$} \\
\hline \multicolumn{6}{|l|}{ Industries } \\
\hline \multicolumn{3}{|c|}{ Manufacturing } & $41,3 \%$ & & \\
\hline \multicolumn{3}{|c|}{ Wholesale \& Retail Trade } & $26,6 \%$ & & \\
\hline \multicolumn{3}{|c|}{ Construction } & $16,5 \%$ & & \\
\hline \multicolumn{3}{|c|}{ Electricity, Energy \& Water Supply } & $4,6 \%$ & & \\
\hline \multicolumn{3}{|c|}{ Transporting \& Storage } & $3,7 \%$ & & \\
\hline \multicolumn{3}{|c|}{ Information \& Communication } & $2,8 \%$ & & \\
\hline \multicolumn{3}{|c|}{ Mining \& Quarrying } & $1,8 \%$ & & \\
\hline \multicolumn{3}{|c|}{ Agriculture \& Forestry } & $0,9 \%$ & & \\
\hline \multicolumn{3}{|c|}{ Human Health \& Social Work Activities } & $0,9 \%$ & & \\
\hline \multicolumn{3}{|c|}{ Real Estate Activities } & $0,9 \%$ & & \\
\hline
\end{tabular}

Figure 3. Number of CEE countries in which firms are active

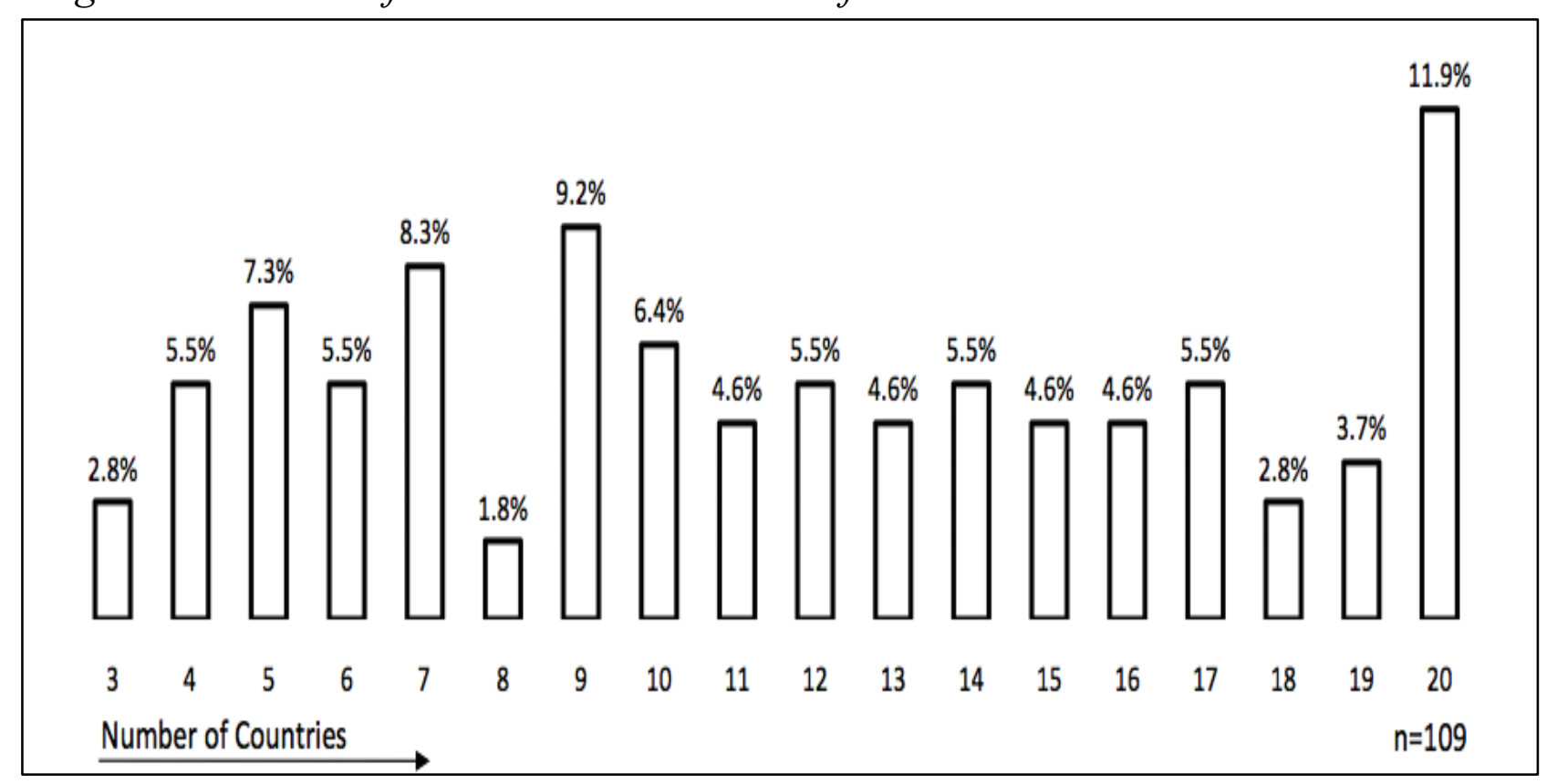


Overall the study registered 1,271 entries into CEE markets. $6 \%$ of all entries were before 1939. These can only be explained by relationships dating back to the Austro-Hungarian Empire. For example, one respondent noted: "Ties to the former regions of the empire were never totally cut off." Between 1939 and $1989,17 \%$ managed to enter the region. The vast majority of entries, $77 \%$, were after the fall of the iron curtain in 1989, 15\% of all entries alone in the year 1990. Overall $47 \%$ of all entries occurred during the nineties and $30 \%$ between 2000 and 2008. This goes in line with the most commonly voiced motive for CEE expansion. As one respondent noticed: "At a time when the domestic market became more and more saturated, Austrian firms more or less suddenly had large, untapped markets in proximity, because of the fall of the iron curtain. Eastern Europe seemed to be the market of tomorrow." Figure 4 provides a detailed table on market entries for each country.

Figure 4. Time of market entries

\begin{tabular}{|c|c|c|c|c|c|c|c|c|c|c|c|c|c|c|c|c|c|c|c|c|}
\hline Entry & $<$ & '39- & & & & & & & & & & & & & & & & & & \\
\hline Year & 39 & ‘89 & ‘90 & '91 & '92 & '93 & '94 & '95 & '96 & ‘ & 9' 98‘ & 00' 90 & ' 01 & '02 & '03 & ‘04 ‘5 & 15 '06 & '07 & ' 08 & 3 Total \\
\hline CZE & 6 & 20 & 16 & 4 & 4 & 7 & 6 & 9 & 1 & 24 & 3 & 2 & 3 & 2 & 12 & 20 & 1 & 0 & 1 & 94 \\
\hline SVK & 6 & 21 & 17 & 4 & 2 & 8 & 7 & 4 & 3 & 2 & 3 & 3 & 3 & 3 & 1 & 2 & 1 & 1 & 1 & 99 \\
\hline HUN & 5 & 30 & 15 & 6 & 4 & 3 & 5 & 4 & 6 & 4 & 3 & 0 & 2 & 4 & 1 & 0 & 1 & 0 & 1 & 102 \\
\hline POL & 5 & 15 & 12 & 2 & 0 & 4 & 6 & 3 & 2 & 2 & 3 & 2 & 3 & 2 & 4 & 1 & 1 & 2 & 1 & 80 \\
\hline SVN & 6 & 18 & 11 & 3 & 3 & 1 & 3 & 2 & 2 & 6 & 3 & 1 & 4 & 3 & 0 & 1 & 0 & 1 & 2 & 79 \\
\hline HRV & 6 & 12 & 10 & 3 & 0 & 1 & 4 & 3 & 2 & 7 & 5 & 3 & 4 & 6 & 2 & 2 & 0 & 1 & 1 & 81 \\
\hline BIH & 2 & 9 & 9 & 3 & 0 & 0 & 1 & 4 & 3 & 4 & 4 & 2 & 1 & 2 & 1 & 1 & 4 & 4 & 2 & 61 \\
\hline SRB & 3 & 11 & 9 & 2 & 0 & 0 & 1 & 2 & 3 & 2 & 3 & 1 & 5 & 3 & 4 & 3 & 3 & 4 & 3 & 70 \\
\hline MNE & 3 & 8 & 9 & 2 & 0 & 0 & 1 & 2 & 1 & 1 & 1 & 2 & 2 & 1 & 0 & 3 & 3 & 4 & 1 & 48 \\
\hline ALB & 4 & 5 & 9 & 2 & 0 & 1 & 0 & 0 & 1 & 1 & 1 & 0 & 1 & 1 & 1 & 4 & 1 & 3 & 5 & 41 \\
\hline MKD & 3 & 6 & 12 & 2 & 0 & 0 & 1 & 1 & 1 & 1 & 2 & 1 & 3 & 0 & 1 & 4 & 2 & 3 & 4 & 51 \\
\hline BGR & 3 & 11 & 11 & 2 & 2 & 1 & 1 & 5 & 1 & 3 & 1 & 5 & 1 & 3 & 3 & 3 & 1 & 5 & 4 & 77 \\
\hline ROU & 4 & 11 & 12 & 2 & 0 & 0 & 3 & 6 & 5 & 5 & 3 & 2 & 3 & 4 & 3 & 7 & 5 & 6 & 1 & 92 \\
\hline MDA & 2 & 3 & 6 & 1 & 0 & 0 & 0 & 3 & 0 & 0 & 1 & 2 & 0 & 0 & 0 & 0 & 1 & 1 & 1 & 26 \\
\hline LVA & 3 & 5 & 6 & 1 & 0 & 1 & 0 & 1 & 0 & 1 & 0 & 4 & 2 & 0 & 2 & 4 & 1 & 1 & 1 & 38 \\
\hline EST & 4 & 5 & 5 & 1 & 0 & 2 & 0 & 1 & 0 & 1 & 1 & 3 & 2 & 0 & 1 & 2 & 2 & 1 & 0 & 36 \\
\hline LTU & 3 & 5 & 6 & 1 & 0 & 2 & 0 & 1 & 0 & 1 & 0 & 5 & 1 & 0 & 2 & 3 & 1 & 2 & 1 & 40 \\
\hline UKR & 3 & 5 & 6 & 1 & 0 & 4 & 0 & 3 & 0 & 2 & 2 & 5 & 1 & 5 & 2 & 3 & 4 & 2 & 5 & 60 \\
\hline BLR & 2 & 5 & 6 & 1 & 0 & 2 & 0 & 1 & 0 & 1 & 2 & 4 & 0 & 2 & 0 & 1 & 2 & 1 & 2 & 36 \\
\hline \multirow[t]{2}{*}{ RUS } & 4 & 10 & 9 & 1 & 1 & 3 & 0 & 3 & 1 & 2 & 2 & 3 & 0 & 3 & 2 & 3 & 3 & 2 & 2 & 60 \\
\hline & $6 \%$ & $17 \%$ & $15 \%$ & $3 \%$ & $1 \%$ & $3 \%$ & $3 \%$ & $5 \%$ & $3 \%$ & $4 \% 6$ & $6 \% 30$ & $\% 4 \%$ & & & & & & & & 1.271 \\
\hline
\end{tabular}

\section{Hypotheses testing and discussion}

With regard to our first hypothesis that proposed low entry modes in the beginning of CEE internationalization and higher modes over time, our study produced interesting results. We found that over $80 \%$ of the firms in our sample follow one of three main strategies. 
$28.4 \%$ of all firms in our sample entered the region via direct investment strategies without later changing their mode in any market. This contradicts our $\mathrm{H} 1$ and shows a new strategy. We can only assume that these Austrian firms had more market knowledge and commitment even in the early years of their CEE internationalization than we would have expected, and thereby entered markets in higher modes. However, similar behaviors have been found by other studies. For example, Barkema and Drogendijk (2007) find supporting evidence for this sort of behavior when analyzing the entry of Dutch companies in the CEE region.

$26.5 \%$ of all firms used a second approach and entered markets via export strategies and then remained in that mode. Again, this contradicts our H1 and shows a new strategy. It seems that these firms did not aim to move into higher entry modes over time. This is in contrast to the Uppsala model, which pictures a pathway that leads to higher modes, and implicitly treats them as the desired final modes. Johanson and Vahlne (1990:12) for instance state: "Thus, the model expects that the internationalization process, once it has started, will tend to proceed regardless of whether strategic decisions in that direction are made or not." Our second strategy was not identified as such by other studies. The reason behind this might be that studies mainly sample firms, which are already active in foreign markets via direct investments and then reproduce their internationalization paths (Barkema/Drogendijk 2007; Juul/Walters 1987; McCarthy/Puffer 1997; Nordström 1991; Pedersen 2000).

The third strategy is reflected by $25.4 \%$ of firms, which entered the region via export strategies and then moved on to higher entry modes. $18.6 \%$ moved on to direct investment strategies, whereas the other $6.8 \%$ moved on to licensing, contract manufacturing, or other, higher export modes (e.g. from indirect export to direct export). This strategy reflects the establishment chain concept and therefore supports our H1. The findings are also in line with some previous studies of market entries into the CEE region (Johanson/Johanson 2006; Salmi 2000).

Figure 5. Early internationalization - Main strategies

\begin{tabular}{|llll|}
\hline & Entry Mode & Final Mode & $\begin{array}{l}\text { Followed by \%o of } \\
\text { firms }\end{array}$ \\
Strategy 1: No Change & Direct Investment & Direct Investment & $28.4 \%$ \\
Strategy 2: No Change & Export & Export & $26.5 \%$ \\
Strategy 3: Establishment & Export & Higher Modes & $25.4 \%$ \\
Chain & & & \\
\hline
\end{tabular}


Figure 6. Early internationalization - Entry and final modes of firms

\begin{tabular}{|cccc|}
\hline & Entry Mode & Final Mode & Change \\
Export & & & \\
Direct Export & $53 \%$ & $32.3 \%$ & $-20.7 \%$ \\
Indirect Export & $43.7 \%$ & $29.4 \%$ & $-14.3 \%$ \\
Export Cooperation & $5.8 \%$ & $2.9 \%$ & $-2.9 \%$ \\
Direct Investment & $2.9 \%$ & $0 \%$ & $-2.9 \%$ \\
Sales Subsidiary & $33 \%$ & $54.9 \%$ & $+21.9 \%$ \\
Manufacturing Joint & $17.5 \%$ & $31.4 \%$ & $+13.9 \%$ \\
Venture & & & \\
Sales Joint Venture & $5.8 \%$ & $6.9 \%$ & $+3.9 \%$ \\
Manufacturing Subsidiary & $4.9 \%$ & $7.8 \%$ & $+2.9 \%$ \\
Contract Manufacturing & $4.9 \%$ & $8.8 \%$ & $+1.1 \%$ \\
Licensing & $7.8 \%$ & $6.9 \%$ & $-0.9 \%$ \\
\end{tabular}

The remaining firms of the sample did not follow any of the main patterns, but showed other individual behavior. Overall we therefore conclude our analysis of $\mathrm{H} 1$ as follows: We have found some evidence in order to support H1. There seems to be a number of Austrian firms, which have entered the region in low entry modes and then progressed into higher modes. We have, however, also found two new strategies. Strategy one leads us to believe that a significant number of firms had sufficient market knowledge and commitment in order to enter CEE markets in higher modes from the beginning. Firms may have achieved this knowledge in different ways. Possible examples may include the use of host country nationals or migrants to generate extended knowledge or prior experiences in these markets by other members of the firm. Strategy two seems to show us that not all firms desire high modes, but purposely remain in low modes. Therefore, the Uppsala model's implication that higher modes are viewed as desired final modes should be questioned. Other authors have also criticized the model's deterministic character with regard to the establishment chain (Hedlund/Kverneland 1985; Holtbrügge 2006; Petersen/Pedersen/Sharma 2003; Turnbull 1987). Other reasons for remaining at the export stage may be strategic issues or scarce resources.

In hypothesis 2 we proposed that in their CEE internationalization, Austrian firms first entered markets with low Psychic Distance, before entering markets with higher Psychic Distance. To test for the effect of Psychic Distance, we used a multidimensional approach. In our data, we first found a strong effect of Geographic Distance as a proxy of psychic distance. As Johanson and Wiedersheim-Paul (1975:308) state: "For obvious reasons, psychic distance is correlated with geographic distance." This is clearly reflected in Figure 3, which pictures the average sequence of market entries by Austrian firms and is especially true for the initial steps of internationalization into the region. The 
first five CEE countries entered by firms are also the geographically closest to Austria (Czech Republic, Slovenia, Hungary, Slovakia and Croatia).

Figure 7. Sequence of market entries
1. Czech Republic
2. Slovenia
3. Hungary
4. Slovakia
5. Croatia
6. Montenegro
7. Poland
8. Estonia
9. Latvia
10. Bosnia and Herzegovina
11. Macedonia
12. Russia
13. Lithuania
14. Albania
15. Bulgaria
16. Moldova
17. Serbia
18. Romania
19. Belarus
20. Ukraine

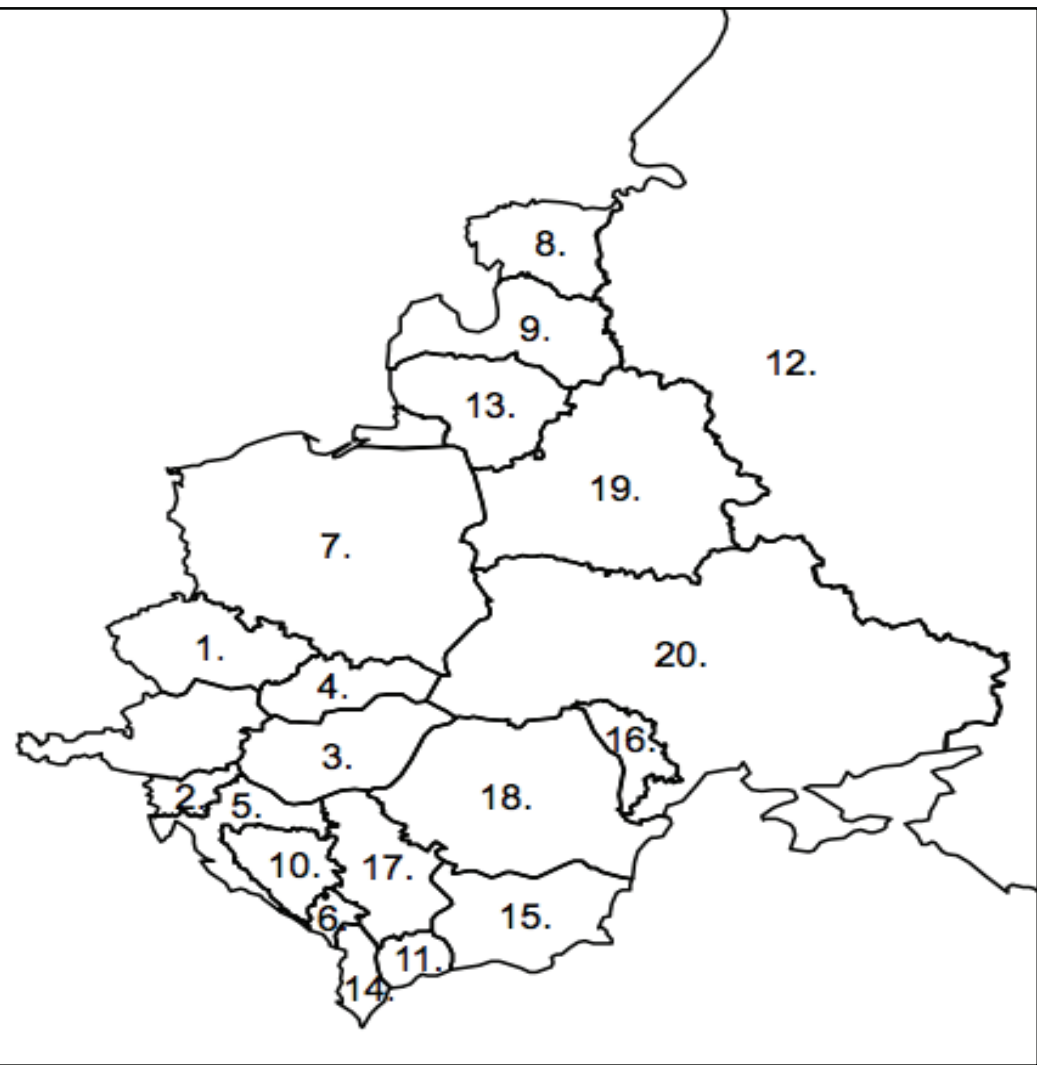

For example, one respondent noted: "Covering the CEE region was set as a strategic objective of the firm. Starting with neighboring countries only seemed logical". Thus, Austrian firms in the sample seemed to have entered nearby markets before distant markets. With regard to Cultural Distance we found no support on a macro level. We found no continuous sign of added cultural distance (measured with the Kogut and Singh (1988) index based on Hofstede (2008) data) from investment to investment. However, strong criticism exists on the measurement of Psychic Distance on macro levels (Stöttinger/Schlegelmilch 1998, Swift 1999). Furthermore, our finding might be explained with Sousa \& Bradley's (2006) results, who found Cultural Distance and Psychic Distance to produce conflicting results, hinting that Cultural Distance might not be an adequate proxy for Psychic Distance (Dow 2000; Ellis 2008). An alternative explanation may be the cultural similarity of a number of countries in CEE. However, we also found no significant effects stemming from experiential knowledge on the micro level. Johanson and Vahlne (1977) cite Penrose (1966:53) differentiating between two types of knowledge: "One type, objective knowledge, can be thought; the other, experience or experiential knowledge, can only be learned through personal experience." Johanson and Vahlne (1977:28) 
further go on: "We believe that this experiential knowledge is the critical kind of knowledge in the present context." Nevertheless, also on the micro level, no significant effects were reported by the interviewees. From our interviews we assume this to be attributed to the fact that managers themselves did not have the possibility to build up market knowledge through personal experience prior to their firms' internationalization, because of the iron curtain. With regard to Hypothesis 2 we can thus state that it could only be verified using Geographic Distance as a proxy for psychic distance, but not applying any other measure on whatever level. Figure 7 offers a picture of the overall average sequence of market entries into countries. Based on our data, we calculated the average entry years of markets and ranked countries accordingly.

In our H3a hypothesis, we proposed that, compared to the early years of CEE internationalization, Austrian firms today enter markets of the region in higher entry modes due to intra- and inter-firm learning. Our results show that in early internationalization $33 \%$ of firms entered markets via direct investment modes, today, $45.5 \%$ do so. This stipulates an increase of $12.5 \%$. A paired sample t-test confirmed that today's entry modes are significantly higher than the modes of early years. As one respondent noticed: "The knowledge of current customers and suppliers which had already internationalized into the CEE region helped us tremendously in our own internationalization into the CEE countries." Therefore, we can confirm H3a and the assumed collective learning processes.

In $\mathrm{H} 3 \mathrm{~b}$ we proposed that compared to the early years of CEE internationalization, Austrian firms today change their mode less often. Analyzing the early internationalization behavior, we see that $51.9 \%$ of firms remained in the same mode in which they entered markets, whereas the other $48.1 \%$ progressed to a different mode over time. For today's internationalization our figures show that $77.9 \%$ remain in the same mode, an increase of $26 \%$ compared to early internationalization. These findings clearly support $\mathrm{H} 3 \mathrm{~b}$. We can state that compared to the early years of CEE internationalization, Austrian firms today change their mode less often. Again, the assumed learning processes seem to have taken place.

$\mathrm{H} 3 \mathrm{c}$ states that compared to the early years of CEE internationalization, Austrian firms today reach higher modes. The hypothesis is based on the same learning processes, which were confirmed in $\mathrm{H} 3 \mathrm{~b}$. Our data, however, shows a surprising, contrasting result. In the early years of internationalization, $54.9 \%$ of firms moved on to direct investment strategies, whereas export strategies were the final modes for $32.3 \%$, contract manufacturing and licensing were the final mode for the remaining $12.8 \%$. Looking at today's internationalization the figures are $49.5 \%$ for direct investment (down by 5.4\%), 38.9\% for export strategies (up by $6.6 \%$ ), and $11.6 \%$ for contract manufacturing and licensing (down by $1.2 \%$ ). These figures show that firms today do not reach higher modes 
compared to early internationalization. Instead, export strategies have grown in importance. Therefore, we have to dismiss H3c.

Figure 8. Today's internationalization - Main strategies

\begin{tabular}{|lccc|}
\hline & Entry Mode & Final Mode & $\begin{array}{c}\text { Followed } \\
\text { by \% of } \\
\text { firms }\end{array}$ \\
Strategy 1: No Change & Direct Investment & Direct Investment & $38.9 \%$ \\
Strategy 2: No Change & Export & Export & $32.6 \%$ \\
Strategy $3:$ Establishment & Export & Higher Modes & $13.7 \%$ \\
Chain & & & \\
\hline
\end{tabular}

Figure 9. Today's internationalization - Preferred entry and final modes of firms

\begin{tabular}{|lccc|}
\hline & Entry Mode & Final Mode & Change \\
Export & $47.5 \%$ & $38.9 \%$ & $-8.6 \%$ \\
Direct Export & $37.9 \%$ & $32.6 \%$ & $-5.3 \%$ \\
Indirect Export & $5.3 \%$ & $3.2 \%$ & $-2.1 \%$ \\
Export Cooperation & $4.2 \%$ & $3.1 \%$ & $-1.1 \%$ \\
Direct Investment & $45.5 \%$ & 49.5 & $+4 \%$ \\
Sales Subsidiary & $26.3 \%$ & $28.4 \%$ & $+2.1 \%$ \\
Manufacturing Joint & & & \\
Venture & $8.4 \%$ & $5.3 \%$ & $+3.1 \%$ \\
Sales Joint Venture & $4.2 \%$ & $4.2 \%$ & $0.0 \%$ \\
Manufacturing Subsidiary & $6.3 \%$ & $11.6 \%$ & $+5.3 \%$ \\
Contract Manufacturing & $3.2 \%$ & $7.4 \%$ & $+4.2 \%$ \\
Licensing & $4.2 \%$ & $4.2 \%$ & $0.0 \%$ \\
\hline
\end{tabular}

We assume the following reasons behind the rejection of $\mathrm{H} 3 \mathrm{c}$. As the results with regard to $\mathrm{H} 3 \mathrm{~b}$ have shown, learning processes, which are the pivotal concept of the Uppsala model, do take place. Additionally, we found evidence of collective learning processes, as described in H3a. However, the increased knowledge about markets, and the increased market commitment do not necessarily have to lead to higher modes, as predicted by the establishment chain. Instead, our data for early and today's internationalization clearly shows the strong importance of export strategies to Austrian firms within the region. A large portion of Austrian firms entered CEE markets via export strategies in the past and remained in that mode. Many Austrian firms still do. Our conclusion is that learning processes have not lead to higher modes, as predicted by the establishment chain. Instead, learning processes have lead firms to take their market entry mode decisions more profoundly - they change their modes less often than they used to (as confirmed in $\mathrm{H} 3 \mathrm{~b}$ ). These more profound decisions are independent from the establishment chain concept. Again, this shows us that the Uppsala model's implication that higher modes are regarded as desired final modes should be questioned. 


\section{Conclusion, implications and limitations}

The internationalization of firms in the CEE region is a challenge to business research and provides a unique opportunity to test the generalization ability of existing theories (Gelbuda/Meyer/Delios 2008; Meyer/Gelbuda 2006; Meyer/Peng 2005). Based on an expanded Uppsala model including collective learning we derived a number of hypotheses explaining the internationalization of Austrian companies in the CEE region.

The majority of our hypotheses have been supported by the empirical data gathered through interviews with managers from Austrian companies active in the region. We found three strategies that Austrian firms applied in their CEE internationalization in the early years. One of which supports the Uppsala model's establishment chain, whereas two of which show new strategies and contradict the model's implication that higher modes are preferred final modes. We were also able to find evidence for the impact of Psychic Distance using Geographic Distance as a proxy. Our hypotheses extending the model further supported the implications of individual and collective learning processes in firm internationalization. Firms' internationalization of today differs from early internationalization by fewer mode changes and higher entry modes. However, results have again indicated the Uppsala model's implication that higher modes are preferred final modes should be questioned. This adds to the criticism of the model's deterministic character by other researchers (e.g., Hedlund/Kverneland 1985; Holtbrügge 2006; Petersen/Pedersen/Sharma 2003; Turnbull 1987). While contributing to the theoretical development of the field by integrating the issue of collective learning processes, we believe our research also to be valuable for the practical field. The collected data provides valuable insights for scholars, practitioners and supporting organizations on the internationalization of Austrian firms in the region. Practitioners could benefit from the insight that most firms do not seem to change their entry modes over time. The initial decision of how to enter a market thereby grows in importance. Furthermore, our study shows that all firms do not follow the Uppsala model's implication that higher modes are regarded as desired final modes. The importance of export strategy for Austrian firms and its persistent use of it is, for example, unexpectedly high. These insights are also especially valuable for supporting organizations. First of all, firms' initial entry mode decision has to be specially supported. Secondly, organizations should focus on supporting the three main internationalization strategies uncovered in our study, which cover more than $80 \%$ of all firms. Finally, practitioners and supporting organizations should try to further benefit from and foster collective learning effects.

There are some limitations to our study. The Uppsala model is not unquestioned in business research. Authors (Andersen 1993; Holtbrügge 2006) especially criticize the model's vagueness and lacking clarity in its operationalization. Further criticism is put on the partial approach of the model. Environmental 
factors such as competitive aspects, country characteristics, or firm specific characteristics, as well as other types of non-experiential learning (e.g. acquisitions) are not implemented (Bäurle 1996; Forsgren 2002; Meyer/Gelbuda 2006). As mentioned above others criticize the model for being too deterministic in its approach. A number of studies have also shown evidence that firms leapfrog stages of the establishment chain (Melin 1992:104; Sullivan/ Bauerschmidt 1990). The most extreme example for such firms are "Born Globals" (Oviatt/McDougall 2005). Furthermore, the concept of Psychic Distance is intensively discussed and criticized in business literature (Ellis 2008; O'Grady/Lane 1996; Stöttinger/Schlegelmilch 2000).

Another limitation of our study is the subjective evaluation by a single firm representative, although we have taken into account various precautions suggested in literature to minimize this bias. This postulates a problem for the validity of our results, although on a relatively low level. Furthermore, during the interviews respondents had to recall information relating back to their firm's first entry into the CEE market, often lying back many years. As such, the results may be influenced to some extent by a memory bias (Chan Kim/Hwang 1992). Finally, we do not know how firms might develop their mode choice in the CEE region in future. One of the main strategies found are firms remaining in export mode. These firms might in future move up the establishment chain to direct investments. Nevertheless, should this be the case, the development would have been much slower than indicated by the Uppsala Model. Our data on average reaches back about 20 years.

Despite these limitations, this paper contributes to both theory and practice. Practitioners may use the results of our study to learn from the internationalization behavior of other firms. With regard to theory, this paper empirically tested the underlying assumptions of the Uppsala model and delivered a valuable extension that may be further elaborated by future studies.

\section{References}

Agarwal, S./Ramaswami, S.N. (1992): Choice of foreign market entry mode: Impact of ownership, location and internalization factors. Journal of International Business Studies, 23, 1, 1-27.

Andersen, O. (1993): On the internationalization process of firms: A critical analysis. Journal of International Business Studies, 24, 2, 209-231.

Anderson, E./Gatignon, H. (1987): Modes of foreign entry: A transaction cost analysis and propositions. International Executive, 29, 1, 15-17.

Barkema, H.G./Drogendijk, R. (2007): Internationalising in small, incremental or larger steps? Journal of International Business Studies, 38, 7, 1132-1148.

Bäurle, I. (1996): Internationalisierung als Prozessphänomen. Konzepte - Besonderheiten Handhabung. Wiesbaden: Gabler. 
Blomstermo, A./Sharma, D.D. (2003): Three decades of research on the internationalisation process of firms, in Blomstermo, A./Sharma, D.D., (ed.), Learning in the internationalisation process of firms, Cheltenham: Edward Elgar Publishing.

Breuss, F. (2006): Ostöffnung, EU-Mitgliedschaft, Euro-Teilnahme und EU-Erweiterung. Wirtschaftliche Auswirkungen auf Österreich, Working Papers. Vienna: Wifo Österreichisches Institut für Wirtschaftsforschung.

Chan Kim, W./Hwang, P. (1992): Global strategy and multinationals' entry mode choice. Journal of International Business Studies, 23, 1, 29-53.

Child, J./Ng, S.H./Wong, C. (2002): Psychic distance and internationalization: Evidence from hong kong firms. International Studies of Management \& Organization, 32, 1, 36-56.

Claver, E./Rienda, L./Quer, D. (2007): The internationalisation process in family firms: Choice of market entry strategies. Journal of General Management, 33, 1, 1-14.

Daniels, J.D./Cannice, M.V. (2004): Interview studies in international business research in Marschan-Piekkari, R./Welch, C., (ed.), Handbook of qualitative research methods for international business, Chelthenham: Edward Elgar Publishing Ltd.

Dow, D. (2000): A note on psychological distance and export market selection. Journal of International Marketing, 8, 1, 51-64.

Ellis, P.D. (2008): Does psychic distance moderate the market size-entry sequence relationship? Journal of International Business Studies, 39, 3, 351-369.

Engelhard, J./Eckert, S. (1995): Market Entry Strategies of German Firms and Industrial Transformation in Eastern Europe, in Culpan, R./Kumar, B.N. (ed.), Transformation management in postcommunist countries: organizational requirements for a market economy, Westport/Conneticut - London, Quorum Books.

Engelhard, J./Blei, C. (1996): Markteintrittsstrategien deutscher Unternehmen in der ehemaligen udssrUdssR, in Welge, M.K./Holtbrügge, D. (ed.), Wirtschaftspartner Russland, Wiesbaden: Gabler.

Forsgren, M. (2002): The concept of learning in the uppsala internationalization process model: A critical review. International Business Review, 11, 3, 257.

Gelbuda, M./Meyer, K.E./Delios, A. (2008): International business and institutional development in Central and Eastern Europe. Journal of International Management, 14, $1,1-11$.

Hedlund, G./Kverneland, A. (1985): Are strategies for foreign markets changing? The case of swedish investment in Japan. International Studies of Management and Organization, $15,2,41-59$.

Hofstede, G. (2008): Cultural dimensions. Retrieved December 1, 2008, from http://www.geert-hofstede.com/hofstede_dimensions.php.

Holtbrügge, D. (2006): Pfadabhängigkeit des Internationalisierungsprozesses? Ein empirischer Test der Lerntheorie der Internationalisierung von Johanson/Vahlne in Unternehmungen der deutschen Automobilindustrie. Zeitschrift für Management, 1, 4, 378-404.

Johanson, J./Vahlne, J.-E. (1977): The internationalization process of the firm - a model of knowledge development and increasing foreign market commitments. Journal of International Business Studies, 8, 1, 25-34. 
Johanson, J./Vahlne, J.-E. (1990): The mechanism of internationalism. International Marketing Review, 7, 4, 11.

Johanson, J./Wiedersheim-Paul, F. (1975): The internationalization of the firm - four swedish cases. Journal of Management Studies, 12, 3, 305-322.

Johanson, M./Johanson, J. (2006): Turbulence, discovery and foreign market entry: A longitudinal study of an entry into the russian market. Management International Review (MIR), 46, 2, 179-205.

Juul, M./Walters, P.G.P. (1987): The internationalisation of norwegian firms - a study of the u.K. Experience. Management International Review (MIR), 27, 1, 58-66.

Kogut, B./Singh, H. (1988): The effect of national culture on the choice of entry mode. Journal of International Business Studies, 19, 3, 411-432.

Lankes, H.P./Venables, A.J. (1996): Foreign direct investment in economic transition: the changing pattern of investments. Economics of Transition, 4, 2, 331-347.

Liu, X./Xiao, W./Huang, X. (2008): Bounded entrepreneurship and internationalisation of indigenous chinese private-owned firms. International Business Review, 17, 4, 488508 .

McCarthy, D.J./Puffer, S.M. (1997): Strategic investment flexibility for mne success in russia: Evolving beyond entry modes. Journal of World Business, 32, 4, 293-319.

Melin, L. (1992): Internationalization as a strategy process. Strategic Management Journal, $13,99-118$.

Meyer, K.E (2001): Institutions, transaction costs, and entry mode choice in Eastern Europe. Journal of International Business Studies, 32, 2, 357-367.

Meyer, K.E./Gelbuda, M. (2006): Process perspectives in international business research in cee. Management International Review (MIR), 46, 2, 143-164.

Meyer, K.E./Peng, M.W. (2005): Probing theoretically into Central and Eastern europe: Transactions, resources, and institutions. Journal of International Business Studies, 36, 6, 600-621.

Nakos, G./Brouthers, K.D. (2002): Entry mode choice of SMEs in Central and Eastern Europe. Entrepreneurship Theory and Practice, 27, 1, 47-63.

Nordström, K.A. (1991): The internationalization process of the firm. Searching for new patterns and explanations, Stockholm School of Economics, Stockholm.

O'Grady, S./Lane, H.W. (1996): The psychic distance paradox. Journal of International Business Studies, 27, 2, 309-333.

Oesterreichische Nationalbank (ed.) (2005): Österreich als Direktinvestor in Osteuropa. Retrieved April,04.2008, from http://www.oenb.at/de/presse_pub/reden/zoellner/ re_20050927_world_investment_report_2005.jsp.

Oesterreichische Nationalbank (ed.) (2009): Stand der österreichischen Direktinvestitionen im Ausland nach Regionen. Retrieved April, 28.2009, from http://www.oenb.at /isaweb/report.do?report $=950.3$.

Oviatt, B.M./McDougall, P.P. (2005): Toward a theory of international new ventures. Journal of International Business Studies, 36, 1, 29-41. 
Pedersen, T. (2000): The internationalization process of danish firms. Gradual learning or discrete rational choices? Journal of Transnational Management Development, 5, 2, 75-89.

Penrose, E. (1966): The theory of the growth of the firm, Oxford: Basil Blackwell.

Petersen, B./Pedersen, T./Sharma, D.D. (2003): The role of knowledge in firms' internationalisation process: Wherefrom and whereto?, in Blomstermo, A./Sharma, D.D. (ed.), Learning in the internationalisation process of firms, Cheltenham: Edward Elgar.

Salmi, A. (2000): Entry into turbulent business networks. European Journal of Marketing, 34, 11/12, 1374-1390.

Sharma, A. (1995): Entry strategies of U.S. Firms to newly independent states, Baltic States, and Eastern European contries. California Management Review, 37, 3, 90-109.

Sharma, A. (2000): Determinants of entry strategies of U.S. Companies into Russia, the Czech Republic, Hungary, Poland, and Romania. Thunderbird International Business Review, 42, 6, 651-676.

Sousa, C.M.P./Bradley, F. (2006): Cultural distance and psychic distance: Two peas in a pod? Journal of International Marketing, 14, 1, 49-70.

Stöttinger, B./Schlegelmilch, B.B. (2000): Psychic distance: A concept past its due date? International Marketing Review, 17, 2/3, 169.

Sullivan, D./Bauerschmidt, A. (1990): Incremental internationalization: A test of johanson and vahlne's thesis. Management International Review (MIR), 30, 1, 19-30.

Swift, J. (1999): Cultural closeness as a facet of cultural affinity. A contribution to the theory of psychic distance. International Marketing Review, 16, 3, 182-201.

Tihanyi, L./Griffith, D.A./Russell, C.J. (2005): The effect of cultural distance on entry mode choice, international diversification, and mne performance: A meta-analysis. Journal of International Business Studies, 36, 3, 270-283.

Turnbull, P.W. (1987): A challenge to the stages theory of the internationalization process, in Rosson, P.J./Reid, S.D. (ed.), Managing export and expansion. London: Greenwood Pub Group Inc.

Uhlenbruck, K. (1997): Entry motives and firm capabilities: Performance implications for foreign direct investment in Central and Eastern Europe. In: Dosier, L.N/Keys J.B. (ed.): Academy of Management Best Paper Proceedings: 204-208. Boston, MA.

UNCTAD (ed.) (2009): FDI/TNC database. Retrieved April 28.2010, from http://www.unctad.org/fdistatistics.

Wiener Institut für Internationale Wirtschaftsvergleiche (ed.) (2007): Database on fdi 2007, Vienna.

Wirtschaftskammern Österreichs (ed.) (2005): Österreichs Direktinvestitionen 2005 in Mittelund Osteuropa. Retrieved April 04.2008, from http://wko.at/statistik/wgraf /wk2006_25direktinvest.htm.

Woodcock, C.P./Beamish, P.W./Makino, S. (1994): Ownership-based entry mode strategies and international performance. Journal of International Business Studies, 25, 2, 253273. 
Zhao, H./Luo, Y./Suh, T. (2004): Transaction cost determinants and ownership-based entry mode choice: A meta-analytical review. Journal of International Business Studies, 35, $6,524-544$. 